\title{
Uczestnictwo ludzi starszych w rekreacji ruchowej a poczucie jakości życia
}

\section{Participation of older people in recreation movement anda sense of quality of life}

An analysis concerns the level of the sense of quality of life among the people $60+$. There has been shown the evaluation of sense of satisfaction with life on a global scale and in selected areas of quality of life among older people not participating in physical recreation at all and four weeks after taking up physical recreation.

Test results: The vast majority of respondents after the participation in recreation is happy with their physical shape, contact with friends, relationships with family and peace of mind. Adoption of physical activity impact on the perception of the ability to perform the duties of everyday life and consciousness of energy level and the will to manage their own lives, including leisure activities according to their own tastes.

Conclusion of the study: Promotion of various forms of physical activities among the elderly can contribute to improvement of their quality of life.

Sprawność fizyczna ma być źródłem i warunkiem pełnego i satysfakcjonującego życia, a nie celem samym w sobie 


\section{Wprowadzenie}

Obecna sytuacja demograficzna w Polsce i na świecie oraz związany z nią rosnący odsetek osób starszych w społeczeństwie zrodziły wiele problemów natury medycznej, społecznej i ekonomicznej. Jest to efekt zmniejszającej się liczby narodzin i coraz większego udziału osób po 60 roku życia w społeczeństwie. W końcu 2014 roku ludność w wieku poprodukcyjnym w Polsce liczyła ponad 7 mln osób, a jej udział w ogólnej populacji wyniósł 19\% (GUS, 2014a) ${ }^{1}$. Wśród ludności w wieku poprodukcyjnym przeważają kobiety, które statystycznie żyją dłużej. Kobiety stanowiły prawie $52 \%$ w ogólnej liczbie ludności według raportu GUS Podstawowe informacje o rozwoju demograficznym Polski do 2014 roku. Według danych przedstawionych w opracowaniu GUS Ludność. Stan i struktura w przekroju terytorialnym w 2014 r. wieku poprodukcyjnego dożyło 2135350 mężczyzn i 4826062 kobiet (GUS, 2014b). Dysproporcja w liczebności kobiet i mężczyzn w późnej dorosłości to tendencja widoczna w wielu państwach. Ostatecznie wzrosła na świecie średnia długość życia dla kobiet do 73 lat a dla mężczyzn do 68 lat, co oznacza, że od 1990 roku zwiększyła się o sześć lat - podano w raporcie Światowej Organizacji Zdrowia, ogłoszonym w Genewie w kwietniu 2014 roku (WHO, 2014). Według danych Głównego Urzędu Statystycznego w 2014 roku w Polsce przeciętne trwanie życia wyniosło u mężczyzn 73,8 lat a u kobiet 81,6 (GUS, 2014c). Postęp medycyny i poprawa warunków codziennej egzystencji przyczyniają się do wydłużania ludzkiego życia, ale czy długowieczność zapewnia życie w zdrowiu i dobrostanie?

W psychologii life-span starość uznaje się za okres rozwojowy, w którym dochodzi do szeregu zmian w sferze biologicznej, psychicznej i społecznej. Mniejsza atrakcyjność wyglądu zewnętrznego, obniżenie się poziomu sprawności fizycznej, choroby, poczucie samotności, poczucie nieużyteczności, niemożliwość wypełnienia wolnego czasu, utrata bliskich, kłopoty finansowe to pierwsze pojawiające się trudności, jakie musi pokonywać człowiek starszy. Czas późnej dorosłości to okres wyciszenia, zasłużonego wypoczynku po wieloletniej pracy i wychowaniu dzieci. Jednak często, niestety, zdarza się tak, że wraz z przejściem na emeryturę pogarsza się wskaźnik jakości życia (Bauman, 2006).

\section{Definicja jakości życia - zadowolenie z życia}

Termin „jakość życia” (QoL, quality of life) po raz pierwszy pojawił się w piśmiennictwie w 1920 roku, użyty przez Pigou, ale we współczesnym rozumieniu został rozpowszechniony w latach 60 . XX wieku w Stanach Zjednoczonych (Wood-Dauphinee, 1999). Natomiast dyskusje o jakości życia zapoczątkowano podczas IX Światowego Kongresu Socjologicznego w 1978 roku w Uppsali. Od tego momentu jakość życia stała się przedmiotem badań przedstawicieli wielu nauk, począwszy od lekarzy i psychologów, aż po socjologów, ekonomistów

\footnotetext{
1 Ludność w wieku poprodukcyjnym, tj. mężczyźni - 65 lat i więcej, kobiety - 60 lat i więcej.
} 
i polityków, co pozwala określić charakter tej kategorii jako interdyscyplinarny. $\mathrm{Na}$ potrzeby opracowania zdecydowano się przyjąć następujące definicje jakości życia: „,poczucie satysfakcji jednostek lub grup społecznych, wynikającej ze świadomości zaspokojenia własnych potrzeb oraz postrzegania możliwości rozwoju jednostkowego i społecznego" (WHO, 1993, s. 153) oraz "odczucie dobrobytu przez jednostkę, jej zadowolenia bądź niezadowolenia” - P. de L. Harwood (Rutkowski, 1984, 87). Wielu autorów zwraca uwagę, że w badaniach jakości życia należy analizować jej wymiar subiektywny i obiektywny. Pośród wyznaczników obiektywnych jakości życia wskazać można między innymi na: poziom materialny, zabezpieczenie finansowe, warunki życia i mieszkania, warunki leczenia, bezpieczeństwo ekologiczne, relacje społeczne, system wsparcia społecznego, aktywność społeczną, rozwój osobisty (edukacja, praca, uczestnictwo w kulturze) czy też rekreację i wypoczynek (Trzebiatowski, 2011). W analizie jakości życia sugeruje się także subiektywną ewaluację życia jako całości bądź też jej komponentów, takich jak kontakty społeczne, zabezpieczenie finansowe czy też zadowolenie z wykonywanego zawodu / zajęcia (Volicer, Bloom-Charette, 1999). Do subiektywnych wskaźników oceny poczucia jakości życia można z kolei zaliczyć poziom stanu zaspokojenia potrzeb takich jak potrzeba bezpieczeństwa i poczucia wewnętrznego spokoju, realizacji życiowych celów oraz aspiracji, stopnia samoakceptacji, dobrostanu psychicznego, akceptacji społecznej czy uznania społecznego. T. Słaby wprowadziła pojęcie tzw. postrzeganej jakości życia (Słaby, 1994), podkreślające subiektywny charakter oceny dokonywanej przez każdego człowieka, pozostającej w dość luźnym związku z kryteriami obiektywnymi poziomu jakości życia. Podejście to jest bardzo istotne, gdyż znacznie częściej psychologiczne uwarunkowania subiektywnej oceny jakości życia mają na tę ocenę większy wpływ niż ujęcie obiektywne. Obszary obserwacji wyznaczone są poprzez określenie zbioru cech oraz dziedzin (sfer, podzbiorów cech) wyznaczających ogólną jakość życia (pełne pole obserwacji) oraz cząstkowe jakości życia (dziedzinowe pole obserwacji) i tworzenia na tej podstawie syntetycznych lub zdezagregowanych (subsyntetycznych lub jednowymiarowych) miar jakości życia (Borys, 2001).

Rozważając problem starzenia się społeczeństwa, należy zadać pytanie: jaka jest jakość życia w wieku senioralnym? Służą temu powszechnie stosowane w ostatnich latach badania oceny jakości życia ludzi starszych: Nottingham Health Profile (NHP) (profil zdrowia), Medical Outcomes Survey Short Form (SF-36), Sickness Impact Profile (SIP), QLQ, WHOQOL-100. Składają się z wielu płaszczyzn, które wpływają na ogólne zadowolenie z życia, w tym zdrowia, właściwe dla warunków mieszkaniowych, zatrudnienia, bezpieczeństwa osobistego i rodzinnego, wzajemnych relacji, edukacji oraz wypoczynku (Kłak, Mińko, Siwczyńska, 2012).

\section{Cel pracy}

Nadrzędnym celem niniejszych badań jest analiza poziomu poczucia jakości życia osób po 60. roku życia oraz ukazanie skali ogólnej oceny poczucia zadowolenia z życia osób starszych przed oraz po podjęciu uczestnictwa w rekreacji ruchowej oraz w wybranych dziedzinach jakości życia. 
Na podstawie analizy literatury dotyczącej badanego problemu sformułowano następujące hipotezy:

1. Podjęcie rekreacji ruchowej jest przyczyną podniesienia poczucia jakości życia - wskutek tego sprawności, niezależności, sprzyjania w nawiązywaniu kontaktów towarzyskich, a nawet opóźniania procesów starzenia się osób starszych.

2. Propagowanie różnych form aktywności fizycznej wśród osób starszych może sprzyjać poprawie jakości ich życia

3. Pozytywny dobrostan związany jest z zaciekawieniem i pierwszymi efektami treningu.

\section{Materiał i metody}

Badanie o charakterze panelowym odbyło się w styczniu i w lutym 2015 roku. Zastosowano metodę sondażu diagnostycznego oraz technikę ankiety. Badania przeprowadzono za pomocą kwestionariusza ankiety własnej w oparciu o skale Notthingam Health Profile, Medical Outcomes Survey Short Form - 36 i Indeks Jakości Życia. Narzędzie badawcze zawierało 40 pytań dotyczących subiektywnej oceny ogólnej i w obrębie wybranych dziedzinowych pól obserwacji jakości życia: zdrowie i funkcjonowanie, uwarunkowania społeczno-ekonomiczne, relacje w rodzinie, duchowość. Pierwsza i druga część zawiera kolejno po 19 i siedem pytań dotyczących między innymi informacji z bloków: zdrowie i funkcjonowanie oraz uwarunkowania społeczno-ekonomiczne. Kolejną badaną dziedziną są relacje w rodzinie, której dotyczą cztery pytania. Ostatnim blokiem jest duchowość, obejmujący 10 pytań.

Na podstawie analizy rozkładów odpowiedzi dotyczących ogólnego i cząstkowego poczucia jakości życia przyjęto, iż wskazanie przez respondenta odpowiedzi w przedziale 1-2 świadczy o negatywnym wartościowaniu danego zjawiska. Wybór na skali jednostki 3 oznaczał podejście ambiwalentne. Odpowiedzi oceniające dany obszar życia w sposób pozytywny obejmowały wartości 4-5 (tabela 1).

Tabela 1. Ocena poczucia jakości życia

\begin{tabular}{|c|c|c|c|c|}
\hline \multicolumn{5}{|c|}{ Ocena poczucia jakości życia } \\
\hline $\begin{array}{c}\text { bardzo } \\
\text { niezadowolona }\end{array}$ & niezadowolona & $\begin{array}{c}\text { ani zadowolona } \\
\text { ani niezadowolona }\end{array}$ & zadowolona & $\begin{array}{c}\text { bardzo } \\
\text { zadowolona }\end{array}$ \\
\hline 1 & 2 & 3 & 4 & 5 \\
\hline
\end{tabular}

Źródło: opracowanie własne.

Dane identyfikujące jakość życia w kategorii zdrowia fizycznego otrzymano w wyniku podsumowania poszczególnych punktów uzyskanych w kwestionariuszu. Zakres całkowitej możliwej punktacji wynosił 19-95 i obejmował ocenę poczucia zadowolenia ze sprawności fizycznej, zdolności do samoobsługi, kontroli 
nad własnym życiem, odporności na zmęczenie, spędzanego czasu wolnego, życia seksualnego, zdolności koncentracji i pamięci. Z kolei jakość życia w kategorii uwarunkowań społeczno-ekonomicznych identyfikowano na podstawie punktacji uzyskanej w trakcie oceny sąsiedztwa, miejsca zamieszkania, pracy, zaspokojenia finansowego, wsparcia przyjaciół. Zakres całkowitej możliwej punktacji w tej kategorii jakości życia wynosił 7-35. Trzecia kategoria pytań obejmowała ocenę poczucia zadowolenia z najbliższej rodziny, gdzie zakres punktacji wynosił od 4 do 20. Ostatnia kategoria dotyczyła oceny duchowości - punktacja od 10-50.

Przy rekrutacji zastosowano metodę „kuli śnieżnej”, która jest nielosową metodą doboru respondentów. Kryterium włączenia do badania był wiek 60 lat i więcej oraz brak uczestnictwa w rekreacji ruchowej. Istotą badania jest porównanie odpowiedzi uzyskanych na cztery tygodnie przed podjęciem uczestnictwa w rekreacji ruchowej oraz cztery tygodnie po podjęciu rekreacji ruchowej. Uczestniczki miały za zadanie uczestniczyć trzy razy w tygodniu przynajmniej 30 min w dowolnie wybranej przez siebie formie rekreacji ruchowej. Najczęstszym rodzajem aktywności preferowanym przez badane był trening ogólnokondycyjny (total body conditioning - TBC), pilates i joga oraz spacery.

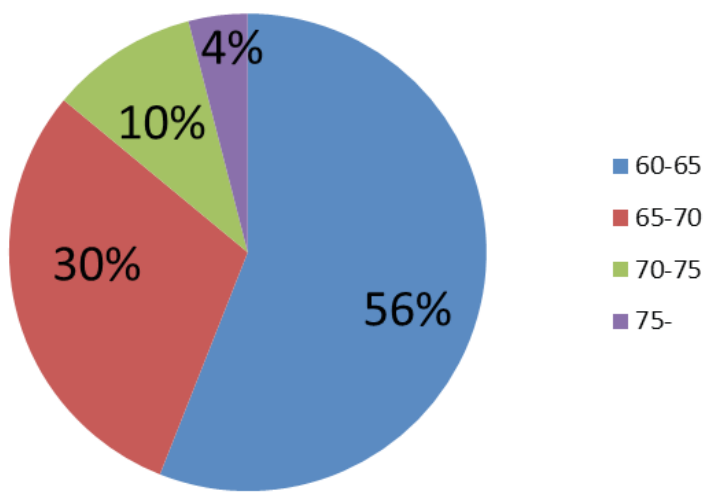

Rycina 1. Struktura wieku respondentów

Źródło: badania własne.

Metoda ta ma swoje minusy, gdyż w badaniu uczestniczyły same kobiety. Uzyskane wyniki w trakcie badania są jednak na tyle interesujące, że postanowiono je zaprezentować, tym bardziej, iż aktualnie realizowany Narodowy Program Zdrowia 2007-2015 w jednym z celów zakłada niwelowanie różnic w zdrowiu. 


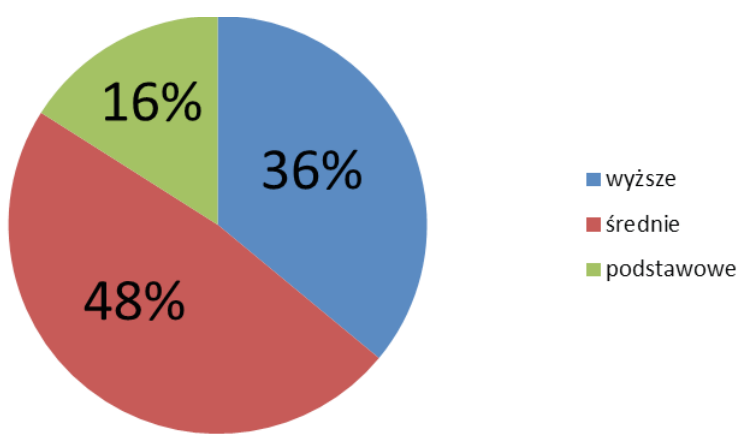

Rycina 2. Struktura wykształcenia respondentów

Źródło: badania własne.

\section{Wyniki}

W badaniu pytano o ogólną i cząstkową ocenę poczucia jakości życia. W pierwszej części wyników przedstawione są interpretacje dotyczące ogólnej oceny poczucia jakości życia. Druga część omówienia poświęcona jest analizie cząstkowej oceny tego zjawiska.

Na podstawie ogólnej oceny poczucia jakości życia zauważono, że wraz z podjęciem uczestnictwa w rekreacji ruchowej nastąpiła marginalna zmiana stosunku do swojego życia w ogóle. 12\% respondentów w dwóch pytaniach zrezygnowało z negatywnej oceny, w jednym pytaniu obserwowany jest spadek bardzo dużego niezadowolenia o 10\%, a w 12 przypadkach utrzymuje się constans (rycina 3).

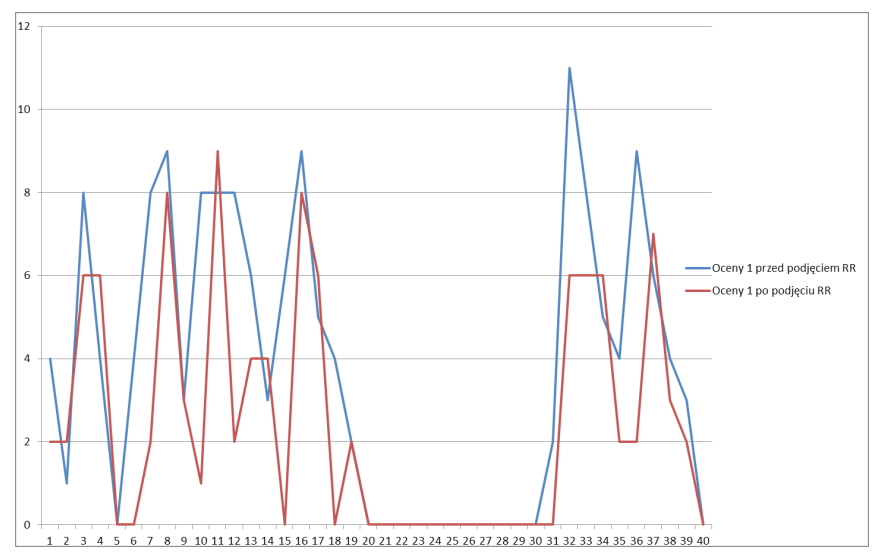

Rycina 3. Stosunek poziomu bardzo dużego niezadowolenia przed podjęciem rekreacji ruchowej do stanu po jej podjęciu

Źródło: badania własne. 
Poziom niezadowolenia badanych po podjęciu uczestnictwa w rekreacji ruchowej obniżył się średnio o 2,35\% (rycina 4). Najwyższy wzrost satysfakcji, o 16\%, odnotowano w pytaniu o powodzenie w realizacji własnych celów.

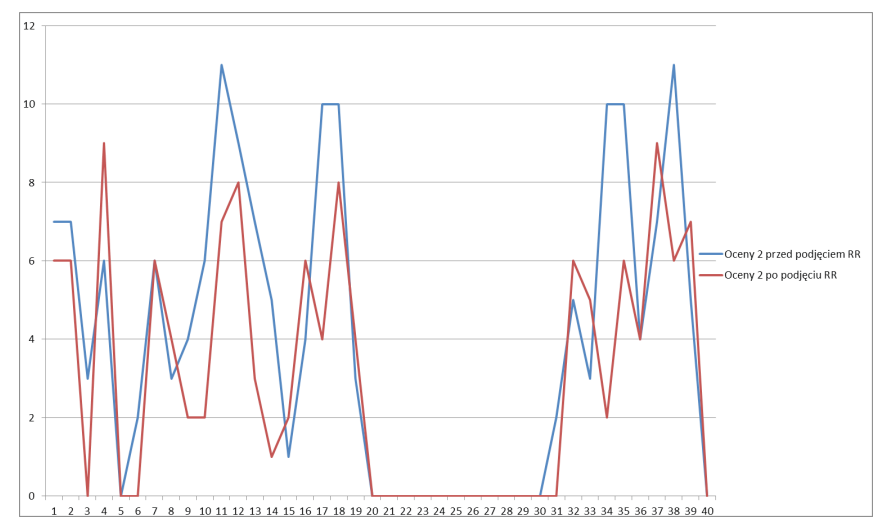

Rycina 4. Stosunek poziomu niezadowolenia przed podjęciem rekreacji ruchowej do stanu po jej podjęciu

Źródło: badania własne.

Z zebranych danych wynika, iż 38,6\% respondentów wycofuje swą deklarację ambiwalentnego stosunku do wybranych aspektów oceny jakości życia. Rekreacyjna aktywność fizyczna spowodowała wzrost poczucia własnej wartości (rycina 5).

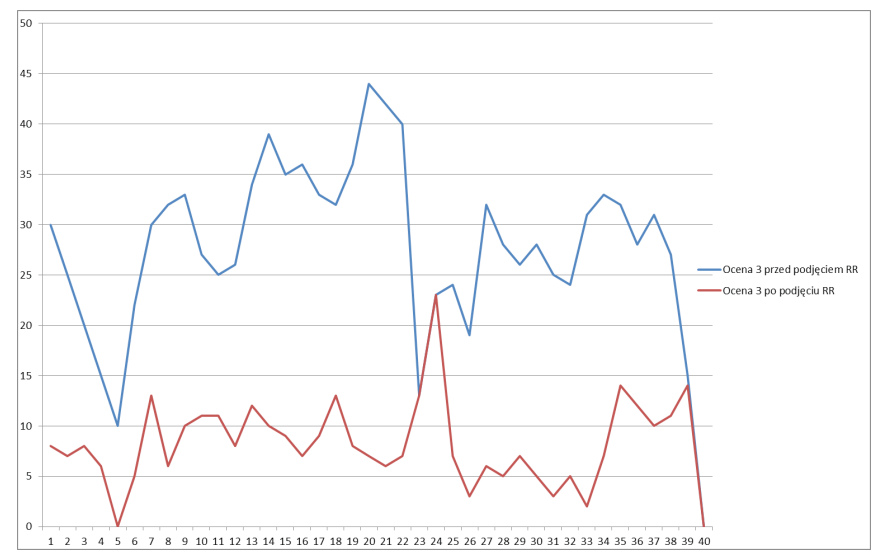

Rycina 5. Stosunek poziomu ambiwalentnego poczucia jakości życia przed podjęciem rekreacji ruchowej do stanu po jej podjęciu

Źródło: badania własne.

Na rycinie 6 uwidoczniono odwrócenie tendencji spadkowej. O 28-35\% nastąpił wzrost liczby odpowiedzi o pozytywnym charakterze oceny poczucia jakości 
życia. Wyniki badania wskazują, że zdecydowana większość respondentów po podjęciu uczestnictwa w rekreacji jest zadowolona ze swojej sprawności fizycznej, kontaktów z przyjaciółmi, relacji z rodziną oraz spokoju ducha.

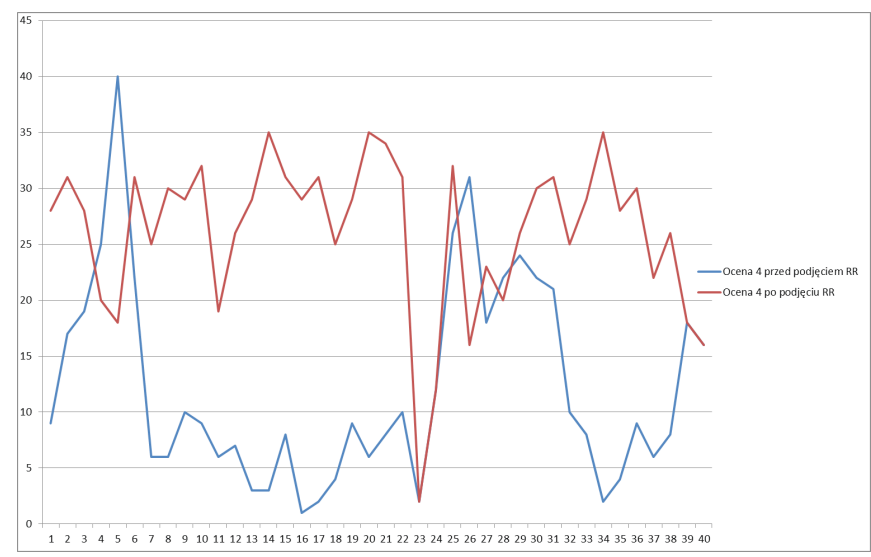

Rycina 6. Stosunek poziomu zadowolenia przed podjęciem rekreacji ruchowej do stanu po jej podjęciu

Źródło: badania własne.

Podobnie jak w przypadku analizowanego wcześniej poziomu zadowolenia, wskaźnik bardzo dużego zadowolenia wzrósł znacząco. Przed rozpoczęciem rekreacyjnej aktywności ruchowej przez badanych wynosił on $2 \%$, natomiast po podjęciu uczestnictwa oscyluje wokół 17-65\%. Niezaprzeczalnie obserwowana jest dysproporcja między deklaracjami ankietowanych przed i po podjęciu rekreacji ruchowej.

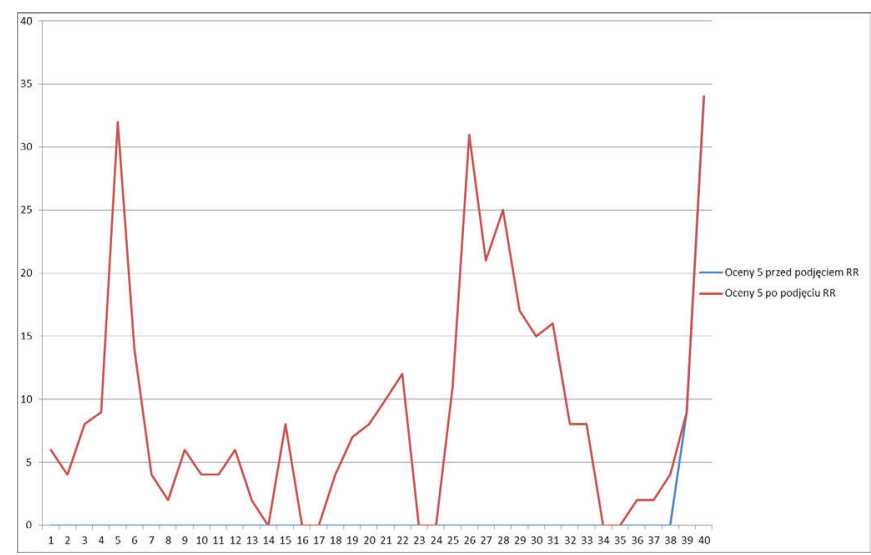

Rycina 7. Stosunek poziomu bardzo dużego zadowolenia przed podjęciem rekreacji ruchowej do stanu po jej podjęciu

Źródło: badania własne. 
Poczucie jakości życia respondentów określonej za pomocą subiektywnej samooceny stanu zdrowia i funkcjonowania przedstawia rycina 8. Przedstawione dane pozwalają jednoznacznie stwierdzić, że podjęcie uczestnictwa w rekreacji ruchowej pozytywnie wpłynęło na postrzeganie zdolności do pełnienia obowiązków w życiu codziennym i świadomość posiadanych pokładów energii oraz wolę kierowania własnym życiem, w tym spędzania czasu wolnego według własnych upodobań. Przeważający odsetek odpowiedzi przed rozpoczęciem rekreacyjnej aktywności ruchowej wskazywał na obojętny stosunek do poczucia zadowolenia w obrębie tego bloku pytań. Po miesiącu regularnych ćwiczeń obserwowano spadek negatywnej i ambiwalentnej oceny poczucia jakości życia na korzyść pozytywnej, czyli wzrost w obrębie wartości 4 - zadowolona i 5 - bardzo zadowolona.

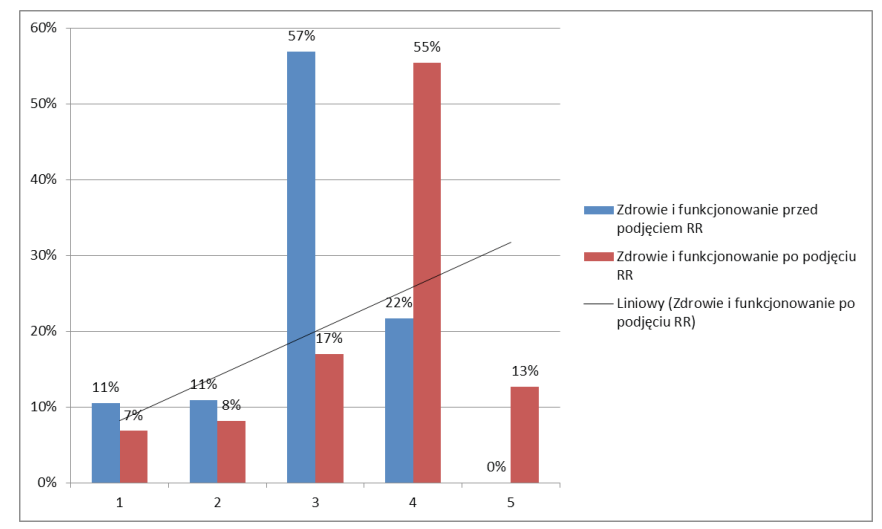

Rycina 8. Wskaźnik poczucia jakości życia w kategorii zdrowia fizycznego przed podjęciem i po podjęciu uczestnictwa w rekreacji ruchowej

Źródło: badania własne.

Powtórne badanie deklaracji w obrębie bloku społeczno-ekonomicznego wskazuje na istotne oddziaływanie uczestnictwa w rekreacji ruchowej. W pierwszej kolejności na uwagę zasługuje stały, zerowy poziom bardzo dużego zadowolenia i niezadowolenia oraz wzrost z najniższego pułapu do $24 \%$ bardzo dużego zadowolenia. Wzrost zadowolenia do $54 \%$ związany jest z akceptacją i wsparciem ze strony przyjaciół. Zmiana stylu życia spowodowała u ankietowanych zdecydowaną poprawę odczuwanej jakości życia, a nawet zmniejszenie dolegliwości z tytułu kłopotów materialnych i finansowych. 


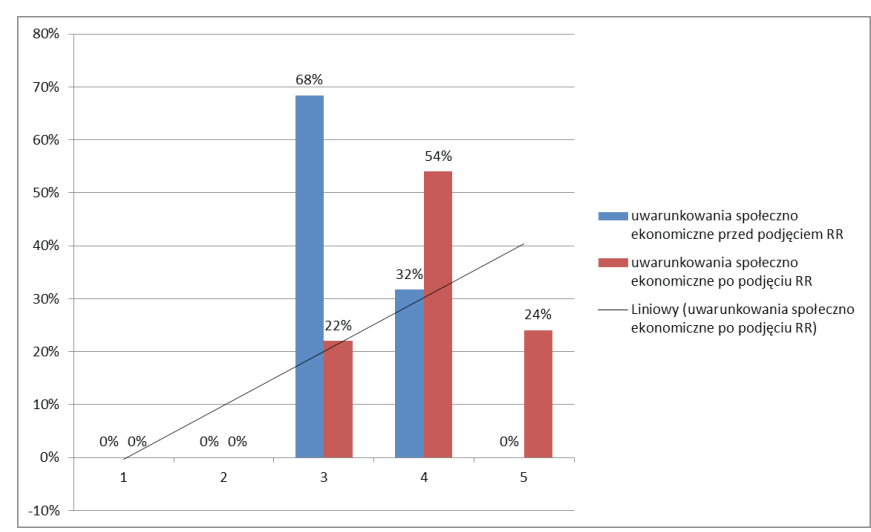

Rycina 9. Wskaźnik poczucia jakości życia w kategorii uwarunkowań społeczno-ekonomicznych przed podjęciem i po podjęciu uczestnictwa w rekreacji ruchowej

Źródło: badania własne.

Rodzina jako podstawowa jednostka społeczna była i jest oceniana przez respondentów tylko w kategoriach poprawnych stosunków oraz dobrych i bardzo dobrych relacji. $12 \%$ respondentów w swych odpowiedziach utrzymuje, iż obawia się o zdrowie najbliższych i szczęście rodzinne. Średnia odpowiedzi przed podjęciem rekreacji ruchowej utrzymuje się na poziomie 3,43, czyli nieco powyżej środkowej wartości. Natomiast po podjęciu rekreacyjnej aktywności wzrasta do 4,275.

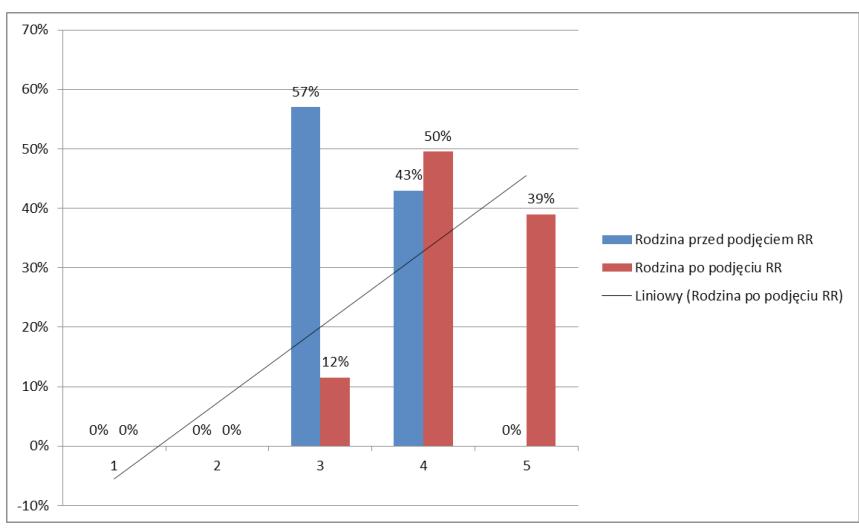

Rycina 10. Wskaźnik poczucia jakości życia w kategorii relacji w rodzinie przed podjęciem i po podjęciu uczestnictwa w rekreacji ruchowej

Źródło: badania własne. 
Przez cztery tygodnie badane seniorki wykazywały się dużym zaangażowaniem podczas systematycznych treningów, a w konsekwencji deklarowały wzrost zadowolenia ze swoich umiejętności przezwyciężania złego nastroju oraz zwiększenie poczucia bezpieczeństwa. O 32\% podwyższył się poziom poczucia zadowolenia ogólnie z samej siebie. $17 \%$ badanych wskazuje bardzo dużą satysfakcję z wyznaczanych i realizowanych przez siebie celów. Zarówno przed podjęciem rekreacji ruchowej, jak i po, respondentki deklarują bardzo pozytywny stosunek do wiary (religii) - średnia odpowiedzi to niezmiennie 4,68.

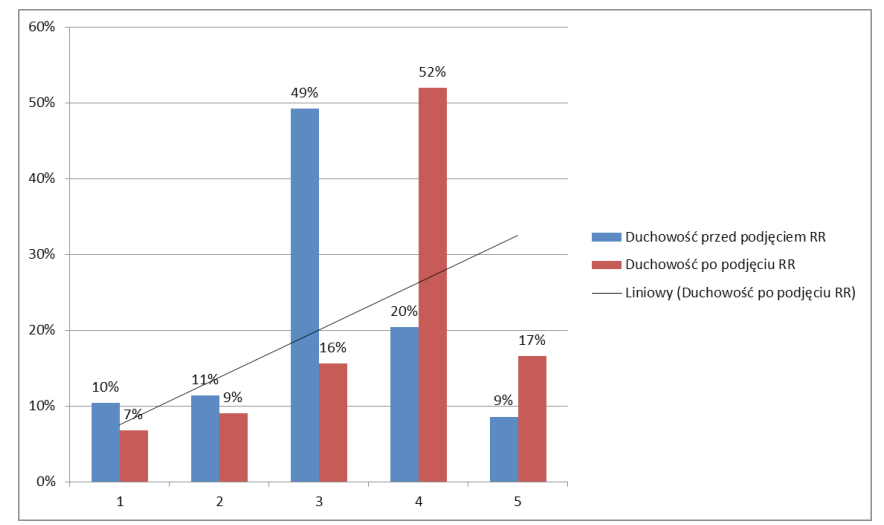

Rycina 11. Wskaźnik poczucia jakości życia w kategorii duchowości przed podjęciem i po podjęciu uczestnictwa w rekreacji ruchowej

Źródło: badania własne.

\section{Podsumowanie i dyskusja}

Postępujący proces starzenia się organizmu, a w konsekwencji pogarszający się stan zdrowia, powodują również, że zmienia się stosunek człowieka do własnego życia we wszystkich jego aspektach: zdrowia, życia rodzinnego, zawodowego i społecznego (Szymańska, Pietryka-Michałowska, Toruń-Jurkowska, 2010). Dlatego też w ocenie stanu zdrowia (oprócz wskaźników biometrycznych) uwzględnia się subiektywne poczucie zdrowia opierające się na przeżyciach osobistych i refleksji nad tym, co odczuwamy i jakimi jesteśmy ludźmi. Źródła emocji zlokalizowane są w nas i w naszym otoczeniu, a „subiektywne ustosunkowanie się do własnego życia w postaci jego oceny jest konsekwencją zaistniałych sytuacji i jednocześnie stanowi psychologiczny aspekt jakości życia" (Kowalik, Janecka, 1998, s. 9). Odczucia subiektywne mają podstawowe znaczenie, ponieważ są udziałem każdego człowieka. Dlatego uzasadnione wydaje się badanie subiektywnej jakości życia, umożliwiające określenie jej poziomu, czynników ją determinujących oraz powiązań występujących między cechami charakteryzującymi jakość życia (Sompolska-Rzechuła, 2010). 
Joanna Grzegorczyk, Andrzej Kwolek, Katarzyna Bazarnik, Ewa Szeliga, Andżelina Wolan (Pracownia Zdrowia Publicznego Instytutu Fizjoterapii Uniwersytetu Rzeszowskiego) badali jakość życia osób mieszkających w DPS i słuchaczy UTW przy użyciu kwestionariusza NHP; wykazali oni, że istotne znaczenie dla ogólnej oceny jakości życia ma większość ocenianych obszarów. Jednak największą zależność stwierdza się pomiędzy jakością życia a sprawnością fizyczną i stanem emocjonalnym. Osoby z większą sprawnością fizyczną lub w dobrym stanie emocjonalnym podają wyraźnie lepszą ocenę jakości. Eksponowane pozytywne oddziaływanie aktywności ruchowej na jakość życia pokrywa się z wynikami badań prowadzonych przez Wojszel u osób po 75. roku życia mieszkających poza instytucjami opiekuńczymi (Wojszel, 1996).

Podobną zależność pomiędzy jakością życia a aktywnością fizyczną wykazała Śmigiel, przeprowadzając badania wśród osób starszych mieszkających we własnych mieszkaniach, jak również w DPS (Śmigiel, 1997). Z badań autorki wypłynął interesujący wniosek wskazujący dwukierunkowy charakter tej zależności (zarówno jakość życia wpływa na aktywność fizyczną, jak i odwrotnie), ale decydującą rolę zmiennej niezależnej przypisuje jakości życia.

Fizjologiczną cechą sprawności ruchowej w życiu dorosłym jest tendencja do jej stopniowego obniżania się wraz z wiekiem. Osoby aktywne ruchowo, które podejmują regularną aktywność fizyczną ponad tę, która dotyczy wysiłków codziennych - funkcjonalnych, mogą utrzymać własną sprawność fizyczną w normie przewidzianej dla wieku. Spadek sprawności fizycznej ponad normę, występujący zwykle u osób nieaktywnych, powoduje, że osobom starszym coraz trudniej jest radzić sobie z czynnościami utylitarnymi - domowymi i samoobsługowymi. W tej sytuacji maleje zdolność osób starszych do zaspokajania własnych potrzeb.

Zgodnie z koncepcja H-RF (health-related fitness), osoby starsze, odnajdując w rekreacji nowe wartości i radość życia, nowe możliwości działania, samorealizację dającą poczucie spełnienia, przyjemności, zabawy i zadowolenia, nie postrzegają starości wyłącznie jako smutnego obrazu rzeczywistości (Kozdroń, 2014). Kiedy kobieta patrzy na siebie przez pryzmat niedoskonałości i defektów osłabia poczucie własnej wartości (Król, Maszorek-Szymala, 2010)

Autoteliczne uczestnictwo w wybranej formie aktywności ruchowej może dostarczać przyjemnych wrażeń i emocji, wspomagając rozwiązywanie problemów zdrowia psychicznego, w tym radzenia sobie ze stresem i panowania nad emocjami (Fox, 1999).

Właściwa rekreacja ruchowa, nie nadmierna, lecz również nie za mała (w stosunku do wieku, płci, budowy ciała) stanowi ważny czynnik zachowania zdrowia (Szwarc, Wolańska, Łobożewicz, 1988).

\section{Wnioski}

1. Osoby uczestniczące w rekreacji ruchowej mają ogólny poziom zadowolenia ze swego stanu zdrowia istotnie statystycznie wyższy niż przed podjęciem rekreacji ruchowej. 
2. Wraz z podjęciem rekreacji ruchowej cząstkowa ocena poczucia jakości życia nie uległa obniżeniu w żadnym z obszarów.

3. Zaobserwowano znaczny wzrost oceny poczucia jakości życia w obrębie kategorii zdrowie i funkcjonowanie.

\section{Literatura}

Baumann K., 2006, Jakość życia w okresie późnej dorosłości - dyskurs teoretyczny, „Gerontologia Polska", t. 14, nr 4, s. 165-171.

Borys T., 2001, Jakość życia a zrównoważony rozwój. Relacje i pomiar, (w:) F. Piontek (red.), Ekonomia a rozwój zrównoważony. Teoria i kształcenie, Wydawnictwo Ekonomia i Środowisko, Białystok.

De Walden-Gałuszko K., 1997, Ocena jakości życia uwarunkowana stanem zdrowia, (w:) J. Meyza, (red.), Jakość życia w chorobie nowotworowej, Centrum Onkologii Instytutu im. Marii Skłodowskiej-Curie, Warszawa, s. 77-82.

Ferrans C.E., Powers M.J., 1992, Psychometric assessment of the quality of life index, „Res Nurs Health", vol. 15, s. 29-38.

Fox K., 1999, The influence of physical activity on mental well-being, „Public Health Nutrition”, vol. 2, s. $411-418$.

GUS, Ludność. Stan i struktura w przekroju terytorialnym w 2014 r., (http://stat.gov.pl/obszary-tematyczne/ludnosc/ludnosc/ludnosc-stan-i-struktura-ludnosci-oraz-ruch-naturalny-w-przekrojuterytorialnym-stan-w-dniu-31-xii-2014-r-,6,17.html), (dostęp: 20.05.2015).

GUS, Trwanie życia w 2014 r., (http://stat.gov.pl/obszary-tematyczne/ludnosc/trwanie-zycia/), (dostęp: 20.05.2015).

GUS, Podstawowe informacje o rozwoju demograficznym Polski do 2014 roku, (http://stat.gov.pl/ download/gfx/portalinformacyjny/pl/defaultaktualnosci/5468/12/5/1/podstawowe_informacje_o_ rozwoju_demograficznym_polski_do_2014.pdf), (dostęp: 20.05.2015).

Kłak A., Mińko M., Siwczyńska D., 2012, Metody kwestionariuszowe badania jakości życia, „Problemy Higieny i Epidemiologii", t. 93(4), s. 632-638.

Kowalik S., Janecka Z., 1998, Użyteczność koncepcji jakości życia dla procesu rehabilitacji osób niepełnosprawnych, Materiały Stowarzyszenia Przyjaciół i Sympatyków Domu Pomocy Społecznej w Jarogniewicach i Katedry Kultury Fizycznej Osób Niepełnosprawnych AWF w Poznaniu, t. 3, Poznań.

Kozdroń E., 2014, Aktywność ruchowa w wychowaniu ku starości - luksus czy konieczność, (w:) A. Zych (red.), Starość darem, zadaniem i wyzwaniem, Stowarzyszenie Przyjaciół Domu Pomocy Społecznej „Pod Dębem” w Dąbrowie Górniczej, Sosnowiec-Dąbrowa Górnicza.

Król K., Maszorek-Szymala A., 2010, Aktywność ruchowa dojrzałych kobiet - moda czy konieczność, „Wychowanie Fizyczne i Zdrowotne”, nr 1, s. 30-33.

McHorney C.A., Ware J.E. Jr, Raczek A.E., 1993, The MOS 36-Item Short-Form Health Survey (SF36): II. Psychometric and clinical tests of validity in measuring physical and mental health constructs, „Medical Care”, vol. 31, s. 247-263.

Narodowy Program Zdrowia na lata 2007-2015, http://www.mz.gov.pl/_data/assets/pdf_ file/0020/12494/zal_urm_npz_90_15052007p.pdf, (dostęp: 20.05.2015).

Polska Agencja Prasowa, Raport WHO- średnia długość życia, http://www.pap.pl/palio/html.run?_Instance $=c m s \_w w w . p a p . p l \& \_P a g e I D=1 \& s=$ infopakiet\&dz=rozmaitosci\&idNewsComp $=\&$ filename $=\&$ idnews $=161875 \&$ data $=$ \&status=biezace\&_CheckSum=-1773504634, (dostęp: 20.05.2015).

Rutkowski J., 1984, Podstawowe pojęcia statystyki społecznej (dokończenie), „Wiadomości Statystyczne", z. 11.

Słaby T., 1994, Systemy wskaźników społecznych w polskich warunkach transformacji rynkowej, „Monografie i Opracowania. Szkoła Główna Handlowa”, nr 392, s. 74-86.

Sompolska-Rzechuła A., 2010, Zastosowanie metody analizy zgodności w badaniu jakości życia kobiet, „Wiadomości Statystyczne”, nr 1, s. 53-65. 
Szwarc H., Wolańska T., Łobożewicz T., 1998, Rekreacja i turystyka ludzi w starszym wieku, Instytut Wydawniczy Związków Zawodowych, Warszawa, s 5.

Szymańska J, Pietryka-Michałowska E, Toruń-Jurkowska A., 2010, Zmienne kulturowe warunkujące dobrostan populacji powyżej sześćdziesiątego roku życia, „Zdrowie Publiczne”, nr 120(1), s. $49-52$.

Śmigiel J., 1997, Poczucie jakości życia a aktywność osób w starszym wieku, „Gerontologia Polska”, nr 5(2), s. 21.

Trzebiatowski J., 2011, Jakość życia w perspektywie nauk społecznych i medycznych - systematyzacja ujęć definicyjnych, „Hygeia Public Health”, vol. 46(1), s. 25-31, http://www.h-ph.pl/pdf/ hyg-2011/hyg-2011-1-025.pdf, (dostęp: 16.01.2015).

Volicer L., Bloom-Charette L., 1999, Enhancing the quality of life in advanced dementia, Brunner/ Mazel, London.

WHO, The World Health Organization Quality of Life (WHOQOL), http://www.who.int/mental_health/ publications/whoqol/en/, (dostęp: 20.02.2015).

The WHOQOL Group, Study protocol for the World Health Organization project to develop a Quality of Life assessment instrument (WHOQOL), Quality of Life Research, 2, 1993, s. 153-159.

Wojszel B., 1996, Uwarunkowania zdrowotne jakości życia oraz ocena stanu zdrowia ludzi starych, „Gerontologia Polska”, nr 4(3), s. 28.

Wood-Dauphinee S., 1999, Assessing quality of life in clinical research: from where have we come and where are we going. „Journal of Clinical Epidemiology”, vol. 52, s. 355-363.

The Word Health Organization Quality of Life assessment (WHO QOL), (1995) position paper from the Word Heath Organization Social Science \& Medicine, 41, s. 1403-1409.

Żołnierczyk-Zreda D, Wrześniewski K, Bugajska J, Jędryka-Góral A., 2009, Polska wersja kwestionariusza SF-36v2 do badania jakości życia, CIOP PIB, Warszawa. 